\begin{tabular}{|c|} 
Jurnal Keolahragaan \\
Volume 4 - Nomor 2, September 2016, (207-219) \\
Tersedia online: http://journal.uny.ac.id/index.php/jolahraga
\end{tabular}

\title{
PENGARUH METODE PEMBELAJARAN DRILL, BERMAIN, DAN KELINCAHAN TERHADAP KEMAMPUAN PASSING DALAM PERMAINAN BOLA VOLI
}

\author{
S. Samsudin ${ }^{1}$, Hari Amirullah Rahman ${ }^{2}$ \\ ${ }^{12}$ Program Studi Ilmu Keolahragaan, Program Pascasarjana, Universitas Negeri Yogyakarta. Jalan \\ Colombo No 1, Karangmalang, Yogyakarta 55281, Indonesia \\ * Korespondensi Penulis. Email: firdaussyam78@yahoo.co.id \\ Received: 16 September 2016; Revised: 3 October 2016; Accepted: 31 October 2016
}

\begin{abstract}
Abstrak
Penelitian ini bertujuan untuk mengetahui: (1) perbedaan pengaruh metode pembelajaran drill dan bermain terhadap kemampuan passing dalam permainan bola voli, (2) perbedaan kemampuan passing bola voli antara metode pembelajaran drill siswa yang memiliki kelincahan tinggi dan bermain siswa yang memiliki kelincahan tinggi, (3) perbedaan kemampuan passing bola voli antara metode pembelajaran drill siswa yang memiliki kelincahan rendah dan bermain siswa yang memiliki kelincahan rendah, dan (4) interaksi antara metode pembelajaran dan kelincahan terhadap kemampuan passing bola voli. Penelitian ini merupakan penelitian eksperimen kuasi dengan pendekatan kuantitatif. Populasi menggunakan siswa SMP Negeri I Ngaglik yang mengikuti kegiatan ekstrakurikuler bola voli sebanyak 38 siswa. Hasil penelitian menunjukkan: (1) ada perbedaan pengaruh antara metode pembelajaran drill dan bermain terhadap kemampuan belajar passing bola voli, (2) ada perbedaan peningkatan kemampuan passing bola voli antara metode pembelajaran drill siswa yang memiliki kelincahan tinggi dan bermain siswa yang memiliki kelincahan tinggi, (3) ada perbedaan kemampuan passing bola voli antara metode pembelajaran drill siswa yang memiliki kelincahan rendah dan bermain siswa yang memiliki kelincahan rendah, (4) ada interaksi antara metode pembelajaran dan kelincahan terhadap kemampuan passing bola voli.
\end{abstract}

Kata Kunci: metode pembelajaran drill, metode pembelajaran bermain, kelincahan, kemampuan passing, bola voli

\section{THE EFFECTS OF DRILL LEARNING METHOD, GAMES AND THE AGILITY ON VOLEYBALL PASSING LEARNING ABILITY}

\begin{abstract}
This study aimed to determine: (1) the differences in the effect of drill learning methods and games learning methods on the increase of voleyball passing ability, (2) the differencess of the increase of the ability of passing volleyball between drill learning method students that have high agility and the games learning methods students who have high agility, (3) the differencess of the increase of the ability of passing volleyball between drill learning methods of students who have low agility and games learning methods of students who have low agility, and (4) the interaction between learning method and agility of the volleyball passing ability. This study was a quasi-experimental study with a quantitative approach. The population in this research is SMP Negeri I Ngaglik students who take part in extracurricular volleyball as many as 38 students. The research results show that: (1) there is a difference between the effect of drill learning methods and games learning methods in the ability to volleyball passing, (2) there is a differences in the increase of volleyball passing ability between drill learning methods students who have high agility and games learning methods that have high agility, (3) there is a difference in the increase of volleyball passing ability between drill learning methods students who have low agility and games learning methods that have low agility. (4) there is an interaction between learning method and agility of the volleyball passing ability.
\end{abstract}

Keywords: drill learning methods, games learning methods, agility, the ability to passing, volleyball.

How to Cite: Samsudin, S., \& Rahman, H. (2016). Pengaruh metode pembelajaran drill, bermain, dan kelincahan terhadap kemampuan passing dalam permainan bola voli. Jurnal Keolahragaan, 4(2), 207 - 219. doi:http://dx.doi.org/10.21831/jk.v4i2.10899

Permalink/DOI: http://dx.doi.org/10.21831/jk.v4i2.10899 


\section{PENDAHULUAN}

Permainan bola voli merupakan salah satu permainan beregu yang menarik, dan tidak membutuhkan biaya yang besar untuk memainkannya. Hanya membutuhkan lahan kosong yang bisa dijadikan lapangan, sebuah net dan bola, permainan ini dapat dilakukan. Inilah yang menjadi salah satu penyebab semakin populer dan digemarinya permainan bola voli di kalangan masyarakat dan di seluruh Indonesia, baik tua, muda, perempuan maupun laki-laki. Selain, itu semakin marak pula adanya pembinaan olahraga bola voli di dalam instansiinstansi perusahaan, pemerintah dan juga lembaga-lembaga pendidikan baik di sekolah dasar (SD), sekolah menengah pertama (SMP), sekolah menengah atas (SMA), sekolah menengah kejuruan (SMK) maupun di perguruan tinggi negeri/swasta (PTN/PTS).

Tujuan dibentuknya pembinaan-pembinaan ini adalah sebagai wadah penyaluran bakat dan minat seseorang dalam bermain bola voli, khusunya bagi anak yang masih dalam usia muda atau usia pertumbuhan, yang pada umumnya masih duduk di bangku SD atau SMP. Dengan dikenalkannya permainan bola voli sejak awal, diharapkan anak mampu memahami, mempelajari, dan memainkan permainan ini dengan baik. Karena dalam usia pertumbuhan, anak lebih cepat menerima suatu hal baru khususnya dalam hal gerak jika diberikan secara teratur dan terarah.

Meskipun demikian, untuk dapat bergerak dan bermain bola voli dengan baik, bagi anak usia muda tidaklah mudah. Butuh waktu dan proses yang panjang agar keterampilan gerak anak dalam bermain bola voli dapat dikuasai dengan baik. Hal ini dikarenakan permainan bola voli merupakan permainan yang menuntut adanya kecepatan, kelentukan, dan kelincahan bagi pemain itu sendiri.

Untuk menjadi pemain bola voli yang baik dituntut menguasai teknik dasar bola voli. Adapun teknik dasar dalam permainan bola voli meliputi servis, passing, block, dan smash/ spike. Dari beberapa teknik dasar yang lebih utama dikuasai yaitu teknik passing. Passing terdiri atas dua macam, yaitu passing bawah dan passing atas. Menurut Wahyuni dan Sutarmin $(2012$, p.5) passing adalah cara memukul bola dengan dua tangan yang disatukan dan diayun dari bawah (passing bawah) atau memukul bola dengan dua tangan terpisah jarijari terbuka di atas kepala agak ke depan (passing atas). Teknik dasar passing bola voli mutlak harus dikuasai oleh pemain bola voli karena bola voli lebih banyak dimainkan dengan cara di-passing sebelum kemudian dismash. Teknik dasar bola voli adalah penguasaan pokok yang harus dipahami dan dikuasai oleh setiap pemain dalam bermain bola voli.

Keberhasilan penguasaan gerakan keterampilan bola voli didukung oleh beberapa faktor penting di antaranya adalah metode pembelajaran yang tepat. Ketertarikan atlet/pelajar untuk mempelajari suatu keterampilan juga disebabkan oleh metode pembelajaran. Metode pembelajaran bisa berbentuk penerapan caracara pembelajaran agar proses belajar bisa berlangsung dengan baik dan tujuannya bisa tercapai.

Oleh sebab itu, penelitian ini dilakukan di SMP Negeri I Ngaglik yang beralamatkan di Kayunan, Donoharjo, Ngaglik, Sleman, Yogyakarta. SMP Negeri I Ngaglik merupakan sekolah yang mengadakan kegiatan ekstrakurikuler yang salah satunya bola voli. Untuk mendukung dan menunjang kegiatan ekstrakurikuler agar tujuan pembelajaran yang diinginkan dapat tercapai, dibutuhkan pemahaman dan kreativitas serta kedisiplinan yang tinggi dari seorang guru yang membimbing ekstrakurikuler agar potensi yang dimiliki setiap siswa yang mengikuti kegiatan ekstrakurikuler dapat benar-benar tersalurkan. Selain itu guru yang membimbing juga harus mampu mengarahkan siswa agar dapat memahami dan menguasai teknik dasar dalam bermain voli, sehingga keterampilan bola voli siswa akan semakin meningkat.

Pemberian metode melatih ekstrakurikuler bola voli dirasa masih kurang bervariasi, hal ini mengakibatkan kemampuan teknik dasar passing siswa masih kurang. Bentuk latihan menarik dan tidak membosankan, serta suasana latihan yang menyenangkan mampu membuat siswa bersemangat dan termotivasi dalam mengikuti kegiatan ekstrakurikuler bola voli. Pada akhirnya diharapkan dapat tercapai peningkatan keterampilan gerak siswa dalam bermain bola voli, terutama dalam hal penguasaan teknik dasar yang baik. Untuk mencapai tujuan pembelajaran ada beberapa faktor yang perlu diperhatikan agar tujuan pembelajaran bola voli dapat tercapai salah satu faktor di antaranya adalah metode pembelajaran yang efektif.

Metode pembelajaran merupakan aspek penting dalam proses pembelajaran. Guru penjaskes perlu mempelajari dan memahami ber- 
bagai metode pembelajaran yang sesuai untuk diterapkan pada anak sesuai tingkatannya. Sudjana (2013, p.76) menyatakan, metode mengajar adalah cara yang dipergunakan guru dalam mengadakan hubungan dengan siswa pada saat berlangsungnya pengajaran.

Oleh karena itu, bentuk metode pembelajaran yang baik untuk meningkatkan kemampuan teknik dasar passing siswa dalam bermain bola voli adalah metode pembelajaran drill dan metode pembelajaran bermain. Dalam bola voli, untuk meningkatkan kemampuan passing siswa bisa menggunakan metode pembelajaran drill dan metode pembelajaran bermain demi perkembangan permainan bola voli. Dengan adanya kedua perbedaan dari kedua metode pembelajaran tersebut, dalam menerapkan kedua metode pembelajaran guru atau pelatih perlu mengetahui faktor-faktor pendukung lainnya salah satunya adalah kelincahan. Kelincahan merupakan salah satu komponen kesegaran jasmani yang sangat diperlukan untuk semua aktivitas yang membutuhkan kecepatan perubahan posisi tubuh dan bagian-bagiannya.

Meskipun demikian, sampai sekarang belum ada guru atau pelatih yang membedakan penerapan kedua metode pembelajaran ini dikaitkan dengan kelincahan. Selama ini semua siswa mendapatkan perlakuan yang sama tanpa membedakan kemampuan dasar yang dimiliki oleh siswa, pada dasarnya setiap siswa mempunyai perbedaan yang perlu diperhatikan untuk mendapatkan peningkatan prestasi secara efektif sesuai dengan kemampuan dasar yang dimiliki setiap siswa. Karena itu, dirasa perlu adanya penelitian yang berkaitan dengan penggunaan metode pembelajaran drill dan metode pembelajaran bermain serta kelincahan, dan seberapa besar pengaruhnya terhadap kemampuan passing dalam permainan bola voli.

Berdasarkan uraian di atas dirasa perlu untuk melakukan penelitian tentang pengaruh metode pembelajaran drill, bermain, dan kelincahan terhadap kemampuan passing dalam permainan bola voli (studi eksperimen metode pembelajaran drill, bermain, dan kelincahan terhadap kemampuan passing dalam permainan bola voli pada siswa SMP Negeri I Ngaglik yang mengikuti kegiatan ekstrakurikuler bola voli).

\section{METODE}

Penelitian ini adalah penelitian eksperimen yang bertujuan untuk membandingkan dua perlakuan yang berbeda kepada subjek peneliti- an dengan menggunakan teknik desain faktorial. Menurut Sudjana (2002, p.148) eksperimen faktorial adalah eksperimen yang hampir atau semua taraf sebuah faktor dikombinasikan atau disilangkan dengan semua taraf tiap faktor lainnya yang ada dalam eksperimen.

Penelitian ini dilaksanakan di SMP Negeri I Ngaglik sebagai tempat pelaksanaan perlakuan (treatment) metode pembelajaran drill dan metode pembelajaran bermain terhadap kemampuan passing dalam permainan bola voli.

Penelitian ini dilaksanakan selama 3 bulan dimulai 28 September 2013 sampai 21 Desember 2013, dengan frekuensi pertemuan 2 kali seminggu yaitu pada hari Sabtu dan Kamis sebanyak 24 kali pertemuan, dilaksanakan di SMP Negeri I Ngaglik, Sleman, Yogyakarta. Lama latihan 90 menit setiap kali pertemuan, latihan dilaksanakan pukul 14.30 s.d. 16.30 WIB.

Subjek dalam penelitian ini adalah siswa SMP Negeri I yang mengikuti kegiatan ekstrakurikuler bola voli. Sampel yang digunakan adalah siswa SMP Negeri I Ngaglik yang mengikuti kegiatan ekstrakurikuler bola voli, besar sampel yang digunakan dalam penelitian adalah sebanyak 24 siswa, yang diperoleh dari keseluruhan populasi.

Sampel penelitian ditentukan dengan cara purposive. Dengan demikian diberikan hal yang sama kepada setiap subjek untuk dipilih menjadi sampel. Teknik pengambilan sampel menggunakan seluruh populasi, jumlah populasi keseluruhan adalah 38 siswa. Dari jumlah populasi 38 siswa tersebut, kemudian dilakukan tes kelincahan yang diperoleh dengan tes lari kelincahan illionis (illionis agility run test) dilakukan sebanyak dua kali dan diambil yang terbaik. Hasil yang didapat kemudian diurutkan skornya dari yang tertinggi sampai yang terendah.

Data hasil kelincahan tersebut dipakai untuk mengelompokkan sampel yang memiliki kelincahan tinggi dan sampel yang memiliki kelincahan rendah. Selanjutnya dari 38 siswa dicari kelincahan tinggi dan kelincahan rendah, sedangkan yang sedang tidak dipakai.

Menurut Miller (2002, p.68) tiga langkah untuk menentukan besar sampel adalah sebagai berikut: (1) mengatur tes dalam rangka menentukan skor tinggi dan skor rendah, (2) menentukan $27 \%$ skor tinggi dan $27 \%$ skor rendah dengan menempatkan dalam satu kelompok yang sama, meskipun $27 \%$ kelompok atas dan 
bawah dianggap yang terbaik untuk memaksimalkan perbedaan antara dua kelompok, atau menggunakan setiap presentasinya $25 \%$ sampai dengan 33\%, dan (3) perhitungan jumlah waktu respons yang benar untuk setiap terpilih pada tes tiap-tiap kelompok.

Dari 38 siswa diperoleh 24 siswa dengan kelincahan tinggi 12 siswa dan kelincahan rendah 12 siswa. Selanjutnya 12 siswa yang mempunyai kelincahan tinggi dan 12 siswa yang mempunyai kelincahan rendah masing-masing dibagi dua kelompok.

Adapun gambaran jumlah sampel dalam penelitian ini dapat dilihat pada Tabel 1.

Tabel 1. Desain Kelompok Penelitian

\begin{tabular}{ccc}
\hline $\begin{array}{c}\text { 19x33\% } \\
\mathbf{6 , 2 7}=\mathbf{6}\end{array}$ & $\begin{array}{c}\text { Latihan dengan } \\
\text { Metode } \\
\text { Pembelajaran } \\
\text { Drill }\end{array}$ & $\begin{array}{c}\text { Latihan dengan } \\
\text { Metode } \\
\text { Pembelajaran } \\
\text { Bermain }\end{array}$ \\
\hline $\begin{array}{c}\text { Kelincahan } \\
\text { tinggi (33\%) }\end{array}$ & 6 orang & 6 orang \\
\hline $\begin{array}{c}\text { Kelincahan } \\
\text { rendah (33\%) }\end{array}$ & 6 orang & 6 orang \\
\hline Total sampel & \multicolumn{2}{c}{24 orang } \\
\hline
\end{tabular}

Dengan demikian diperoleh sampel dalam penelitian ini, untuk kelompok eksperimen pembelajaran metode drill dengan memiliki kelincahan tinggi 6 orang, dan memiliki kelincahan rendah 6 orang, berjumlah 12 orang. Di sisi lain, untuk kelompok eksperimen pembelajaran metode bermain yang memiliki kelincahan tinggi berjumlah 6 orang, dan memiliki kelincahan rendah 6 orang, berjumlah 12 orang. Total sampel keseluruhannya 24 orang.

\section{Prosedur Penelitian Eksperimental}

Prosedur penelitian ini sejalan dengan langkah-langkah penelitian menurut Arikunto (2010, p.61) yang terdiri atas sebelas langkah yaitu: (1) memilih masalah, (2) studi pendahuluan, (3) merumuskan masalah, (4) merumuskan anggapan dasar. 4a. merumuskan hipotesis, (5) memilih pendekatan, (6) a. menentukan variabel, dan b. sumber data, (7) menentukan dan menyusun instrumen. (8) mengumpulkan data, (9) analisis data, (10) menarik kesimpulan, (11) menulis laporan. Langkah ke-1 sampai dengan ke6 mengisi kegiatan pembuatan rancangan penelitian. Langkah ke-7 sampai dengan ke10 merupakan pelaksaan penelitian, dan langkah terakhir atau ke-11 sama dengan pembuatan laporan penelitian.

\section{Desain Penelitian Eksperimental (Experimental Design)}

Dalam penelitian ini disusun suatu kerangka desain penelitian dengan rancangan faktorial $2 \times 2$ seperti Tabel 2 .

Tabel 2. Kerangka Desain Penelitian

\begin{tabular}{lcc}
\hline & \multicolumn{2}{c}{ Metode Pembelajaran } \\
\cline { 2 - 3 } Variabel Atribut & $\begin{array}{c}\text { Metode } \\
\text { Pembelajaran } \\
\text { Drill }\left(\mathrm{A}_{1}\right)\end{array}$ & $\begin{array}{c}\text { Metode } \\
\text { Pembelajaran } \\
\text { Bermain }\left(\mathrm{A}_{2}\right)\end{array}$ \\
\hline $\begin{array}{l}\text { Kelincahan Tinggi } \\
\left(\mathrm{B}_{1}\right)\end{array}$ & $\mathrm{A}_{1} \mathrm{~B}_{1}$ & $\mathrm{~A}_{2} \mathrm{~B}_{1}$ \\
$\begin{array}{l}\text { Kelincahan Rendah } \\
\left(\mathrm{B}_{2}\right)\end{array}$ & $\mathrm{A}_{1} \mathrm{~B}_{2}$ & $\mathrm{~A}_{2} \mathrm{~B}_{2}$ \\
\hline
\end{tabular}

Keterangan:

$\mathrm{A}_{1} \mathrm{~B}_{2}$ : Kelompok siswa yang memiliki kelincahan tinggi dilatih menggunakan metode drill.

$A_{2} B_{1}$ : Kelompok siswa yang memiliki kelincahan tinggi dilatih menggunakan metode bermain.

$\mathrm{A}_{1} \mathrm{~B}_{2}$ : Kelompok siswa yang memiliki kelincahan rendah dilatih menggunakan metode drill.

$A_{1} B_{2}$ : Kelompok siswa yang memiliki kelincahan rendah dilatih menggunakan metode bermain.

\section{Data, Instrumen, dan Teknik Pengumpulan Data}

Jenis data yang diperoleh dalam penelitian ini berupa data kuantitatif. Data kuantitatif berasal dari: (1) data dari hasil tes kelincahan, (2) data dari hasil pretest (tes awal) kemampuan passing siswa, dan (3) data dari hasil posttest (tes akhir) kemampuan passing siswa. Datadata tersebut untuk mengevaluasi perbedaan pengaruh antara metode pembelajaran drill dan metode pembelajaran bermain serta kelincahan terhadap kemampuan belajar passing dalam permainan bola voli pada siswa SMP Negeri I Ngaglik yang mengikuti kegatan ekstrakurikuler.

Instrumen yang digunakan untuk pengumpulan data dalam penelitian eksperimental ini yaitu: Pertama, tes kelincahan menggunakan illionis agility run test dengan alat dan perlengkapan terdiri atas: (1) area lapangan yang luasnya $40 \mathrm{~m}$, (2) 8 cone (tanda bentuk kerucut), (3) stopwatch, (4) alat tulis, dan (5) blangko pencatat nilai skor.

Kedua, tes kemampuan passing menggunakan braddy volleyball test dengan alat dan perlengkapan terdiri atas: (1) dinding tembok 
yang halus dan rata, (2) blangko penilaian, (3) stopwatch, (4) alat tulis, dan (5) bola voli

Teknik pengumpulan data pertama yaitu tes kelincahan dengan menggunakan instrumen illionis agility run test sebagai alat pengumpulan data. Dalam pelaksanaannya, menandai area lapangan dengan luas $10 \times 5$ meter, kemudian meletakkan 4 cone pada setiap ujung lapangan. Ujung kiri lapangan yang terdapat sebuah cone diberi tanda start dan ujung kanan lapangan yang terdapat sebuah cone diberi tanda finish. Meletakkan 4 cone lainnya pada area pertengahan lapangan, dan setiap cone jaraknya 3,3 meter. Siswa mulai berdiri di depan conestart, kemudian asisten menjelaskan jalur lari yang harus dilakukan sampai finish. Pada saat asisten memberikan aba-aba "go", siswa lari secepat mungkin mengikuti jalur lari sampai finish, sementara asisten menjalankan stopwatch. Selama lari siswa tidak boleh menyentuh cone. Waktu yang ditempuh sampai finish dicatat. Illionis agility run test dapat dilihat Gambar 1 .

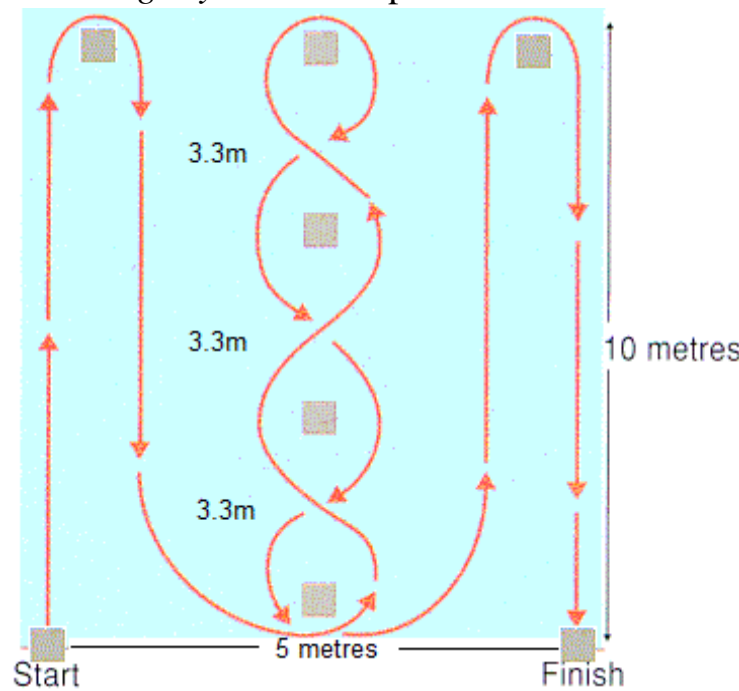

Gambar 1. Tes Lari Kelincahan Illionis/Illionis Agility Run Test

Teknik pengumpulan data yang kedua yaitu tes kemampuan passing dengan menggunakan instrumen braddy volleyball test. Brady volleybal test ini digunakan untuk tes kemampuan passing siswa. Tes dilakukan sebanyak dua kali, yaitu pretest (tes awal) dan posttest (tes akhir). Pretest dilakukan untuk mengukur kemampuan passing siswa dalam bermain bola voli sebelum siswa mempelajari teknik bermain bola voli. Posttest adalah tes yang dilakukan guna mengukur kemampuan siswa setelah mempelajari teknik dasar bermain bola voli. Guru mengajarkan teknik dasar bermain bola voli sesuai dengan program latihan siswa kemudian dites kemampuannya bermain bola voli, khususnya kemampuan passing. Penentuan skor dengan teknik braddy volleyball test. Menurut Ngatman (2001, p.9) penentuan skor dihitung berdasarkan jumlah bola yang sah mengenai garis sasaran selama 60 detik (1 menit) dan setiap bola yang sah tersebut diberi skor 1. Dalam penelitian ini skor tes dengan menggunakan teknik braddy volleyball test yang dimodifikasi ini juga mengacu pada pemberian skor braddy volleyball test itu sendiri, yaitu skor adalah jumlah bola yang sah yang dipassing mengenai sasaran selama 60 detik (1 menit). Skor dihitung dari bola yang di-passing masuk ke daerah sasaran serta mengenai garis batas daerah sasaran. Setiap bola yang sah tersebut diberi skor satu. Tes ini dilakukan dua kali kesempatan yang dipakai yang terbaik. Braddy volleyball test dapat dilihat Gambar 2:

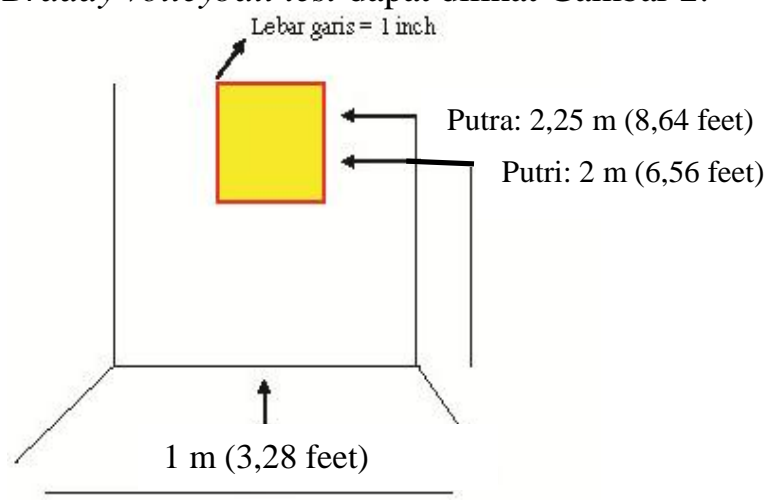

Gambar 2. Braddy Volleyball Test

Keterangan:

1. Daerah kotak sasaran 1 meter.

2. Lebar garis daerah kotak sasaran 1 inci.

3. Tinggi daerah kotak sasaran

a. Putra 2.25 meter.

b. Putri 2 meter.

4. Jarak tembok sasaran dengan berdirinya testi (siswa) 1 meter.

\section{Pelaksanaanya:}

Testi berdiri menghadap daerah sasaran dengan bola voli di tangan, setelah ada aba-aba dari petugas, testi mulai melempar bola ke tembok, bola memantul dari tembok di-passing ke daearah/kotak sasaran. Apabila bola luncas atau sulit dikuasai, bola dapat dipegang atau diambil kembali, lalu mulai lagi dengan melempar bola ke tembok (kotak sasaran) untuk di-passing sampai waktunya habis. Waktunya 60 detik (1 menit). Setiap bola yang memantul dari tembok, lalu di-passing masuk ke daerah sasaran serta mengenai garis daerah kotak sasaran 
diberi skor 1. Bola yang dilempar ke tembok tidak diberi skor. Skor tes adalah jumlah skor passing testi selama 60 detik (1 menit). Tes dilakukan dua kali kesempatan, diambil yang terbaik.

\section{Teknik Analisis Data}

Teknik analisis data yang dilakukan dalam penelitian ini yaitu analisi kuantitatif. Analisis kuantitatif ini dilakukan untuk menganalisis data tes kemampuan passing siswa (pretest dan posttest). Sebelum dilakukan pengujian hipotesis, perlu dilakukan uji prasyarat. Pengujian terhadap data hasil pengukuran yang berhubungan dengan hasil penelitian bertujuan untuk membantu dalam hal analisis agar menjadi lebih baik. Untuk itu dalam penelitian ini akan dihitung normalitasnya dan penghitungan homogenitas data. Adapun teknik analisis data yang digunakan dalam penelitian ini adalah sebagai berikut:

\section{Uji Normalitas}

Penghitungan normalitas sampel adalah pengujian terhadap normal tidaknya data yang dianalisis. Uji yang digunakan adalah uji kolmogorov smirnov.

\section{Uji Homogenitas}

Penghitungan homogenitas dimaksudkan untuk meyakinkan agar kelompok yang membentuk sampel berasal dari populasi yang sama. Uji homogenitas menggunakan uji Levene's test dengan uji F.

\section{Uji Hipotesis Penelitian}

Untuk menguji hipotesis penelitian dilakukan dengan menggunakan analisis varian (Anava) yaitu dengan menggunakan program SPSS komputer dengan taraf signifikansi $5 \%$ atau 0,05 . Uji ini dilakukan untuk mengetahui perbedaan rerata nilai dari variabel antara pretest dan posttest pada kelompok eksperimen dan mengetahui perbedaan pengaruh antarvariabel.

\section{HASIL DAN PEMBAHASAN}

\section{Data Kemampuan Belajar Passing}

Tes kemampuan belajar passing dalam penelitian ini menghasilkan dua macam data, yaitu data skor pretest kemampuan belajar passing dan data skor posttest kemampuan belajar passing dalam permainan bola voli. Data ini baik yang menggunakan metode pembelajaran drill maupun metode pembelajaran bermain. Hasil penelitian kemampuan belajar passing disajikan sebagai berikut:

\section{Pretest Kemampuan Belajar Passing} Menggunakan Metode Pembelajaran Drill

Subjek pada pretest kemampuan belajar passing dengan menggunakan metode pembelajaran drill sebanyak dua belas siswa. Hasil pretest kemampuan belajar passing dengan menggunakan metode pembelajaran drill memiliki nilai terendah adalah 2,00 dan nilai tertinggi sebesar 20,00. Dengan komputer program SPSS diketahui bahwa skor rerata (mean) yang dicapai siswa pada saat pretest kemampuan belajar passing sebesar 7,83; median sebesar 7,00; mode sebesar 2,00, dan SD sebesar 5,73.

Selanjutnya jumlah kelas dapat dihitung dengan menggunakan rumus $1+3.3 \log \mathrm{n}$, dengan $\mathrm{n}$ adalah subjek penelitian. Dari perhitungan diketahui bahwa $\mathrm{n}=12$ sehingga diperoleh banyak kelas $1+3.3 \log 12=4,56$ dibulatkan menjadi 5 kelas interval. Rentang data dihitung dengan rumus nilai maksimal nilai minimal, sehingga diperoleh rentang data sebesar 20,0 - 2,0 = 18,0. Dengan diketahui rentang data dapat diperoleh panjang kelas sebesar 3,6.

Tabel distribusi frekuensi variabel pretest kemampuan belajar passing dengan menggunakan metode pembelajaran drill disajikan sebagai berikut:

Tabel 3. Distribusi Frekuensi Variabel Pretest Kemampuan Belajar Passing dengan Menggunakan Metode Pembelajaran Drill

\begin{tabular}{ccccccl}
\hline No. & \multicolumn{2}{c}{ Interval } & Frekuensi & Persentase & \multicolumn{1}{c}{ Klasifikasi } \\
\hline 1. & 16,8 & - & 20,4 & 1 & $8,3 \%$ & Baik sekali \\
2. & 13,1 & - & 16,7 & 1 & $8,3 \%$ & Baik \\
3. & 9,4 & - & 13,0 & 1 & $8,3 \%$ & Sedang \\
4. & 5,7 & - & 9,3 & 4 & $33,3 \%$ & Kurang \\
5. & 2,0 & - & 5,6 & 5 & $41,7 \%$ & Kurang sekali \\
\multicolumn{2}{r}{ Jumlah } & 12 & $100,0 \%$ & \\
\hline
\end{tabular}

(Sumber: Data primer yang diolah, 2014) 


\section{Jurnal Keolahragaan 4 (2), September 2016 - 213}

S. Samsudin, Hari Amirullah Rahman

Berdasarkan distribusi frekuensi variabel pretest kemampuan belajar passing dengan menggunakan metode pembelajaran drill digambarkan Gambar 3.

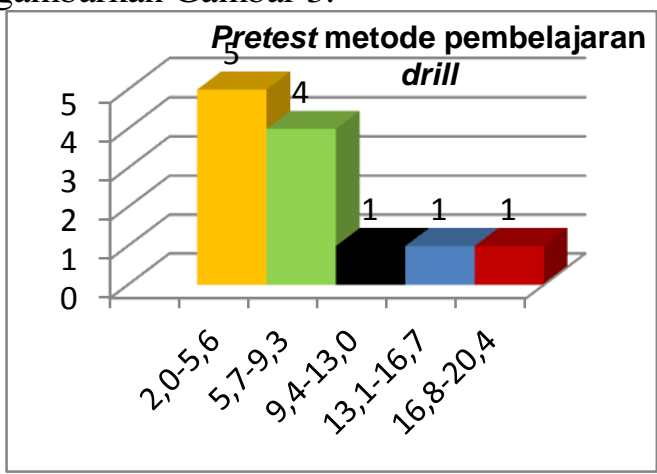

Gambar 3. Distribusi Frekuensi Variabel Pretest Kemampuan Belajar Passing dengan Menggunakan Metode Pembelajaran Drill

Berdasarkan Tabel 3 dan Gambar 3, frekuensi variabel pretest kemampuan belajar passing dengan menggunakan metode pembelajaran drill mayoritas terdapat pada interval 2,0-5,6 sebanyak 5 siswa $(41,7 \%)$, sedangkan paling sedikit terdapat pada interval 9,4-13,0, interval 13,1-16,7, dan interval 16,8-20,4 masing-masing sebanyak 1 siswa $(8,3 \%)$. Sisanya berada pada interval 5,7-9,3 sebanyak 4 siswa.

Posttest Kemampuan Belajar Passing Menggunakan Metode Pembelajaran Drill

Hasil posttest kemampuan belajar passing dengan menggunakan metode pembelajaran drill skor terendah adalah 6,00 dan skor tertinggi yang dicapai siswa adalah 39,00. Dengan komputer program SPSS diketahui bahwa skor rerata (mean) yang diraih siswa yang menggunakan metode pembelajaran drill pada saat posttest sebesar 18,25; median 17,00; mode sebesar 6,00; dan SD sebesar 11,2.

Selanjutnya jumlah kelas dapat dihitung dengan menggunakan rumus $1+3.3 \log \mathrm{n}$, dengan $n$ adalah subjek penelitian. Dari perhitungan diketahui bahwa $n=12$ sehingga diperoleh banyak kelas $1+3.3 \log 12=4,6$ dibulatkan menjadi 5 kelas interval. Rentang data dihitung dengan rumus nilai maksimal - nilai minimal, sehingga diperoleh rentang data sebesar $39-6=33$. Dengan diketahui rentang data dapat diperoleh panjang kelas sebesar 6,6.

Distribusi frekuensi variabel posttest kemampuan belajar passing dengan menggunakan metode pembelajaran drill disajikan Tabel 4. Berdasarkan distribusi frekuensi variabel posttest kemampuan belajar passing dengan menggunakan metode pembelajaran drill tersebut pada Gambar 4. Tabel 4 dan Gambar 4 tersebut, frekuensi variabel posttest kemampuan belajar passing dengan menggunakan metode pembelajaran drill mayoritas terdapat pada interval 6,0-12,6 sebanyak 5 siswa $(41,7 \%)$, sedangkan paling sedikit pada interval 26,1-32,7 sebanyak 1 siswa $(8,3 \%)$. Sisanya berada pada interval $32,8-39,4$, interval 19,4-26,0, dan interval 12,719,3 masing-masing sebanyak 2 siswa $(16,7 \%)$.

Tabel 4. Distribusi Frekuensi Variabel Posttest Kemampuan Belajar Passing dengan Menggunakan Metode Pembelajaran Drill

\begin{tabular}{ccccccc}
\hline No. & \multicolumn{2}{c}{ Interval } & Frekuensi & Persentase & Klasifikasi \\
\hline 1. & 32,8 & - & 39,4 & 2 & $16,7 \%$ & Baik sekali \\
2. & 26,1 & - & 32,7 & 1 & $8,3 \%$ & Baik \\
3. & 19,4 & - & 26,0 & 2 & $16,7 \%$ & Sedang \\
4. & 12,7 & - & 19,3 & 2 & $16,7 \%$ & Kurang \\
5. & 6,0 & - & 12,6 & 5 & $41,7 \%$ & Kurang sekali \\
\end{tabular}

(Sumber: Data primer yang diolah, 2014)

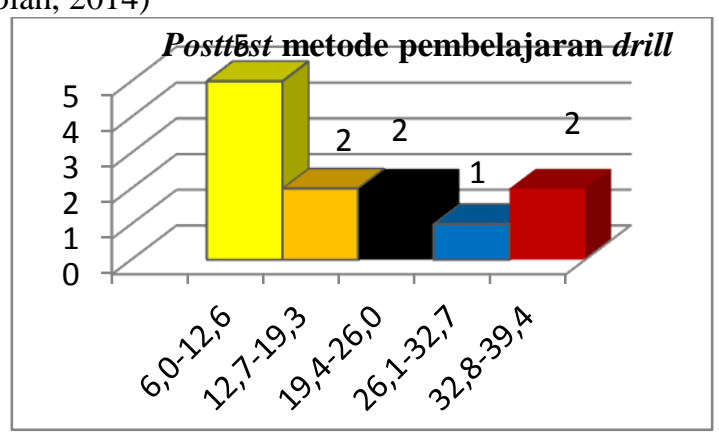

Gambar 4. Distribusi Frekuensi Variabel Posttest Kemampuan Belajar Passing dengan Menggunakan Metode Pembelajaran Drill 


\section{Jurnal Keolahragaan 4 (2), September 2016 - 214}

S. Samsudin, Hari Amirullah Rahman

Pretest Kemampuan Belajar Passing Menggunakan Metode Pembelajaran Bermain

Subjek pada pretest kemampuan belajar passing dengan menggunakan metode pembelajaran bermain sebanyak dua belas siswa menunjukkan bahwa skor terendah adalah 0,00 dan skor tertinggi yang dicapai siswa adalah 21,00 . Dengan komputer program SPSS diketahui bahwa skor rerata (mean) yang diraih siswa sebesar 5,50; median 4,50; mode sebesar 5,00; dan standar deviasi sebesar 5,78.

Selanjutnya jumlah kelas dapat dihitung dengan menggunakan rumus $1+3.3 \log \mathrm{n}$, dengan $\mathrm{n}$ adalah subjek penelitian. Dari perhitungan diketahui bahwa $\mathrm{n}=12$ sehingga diperoleh banyak kelas $1+3.3 \log 12=4,56$ dibulatkan menjadi 5 kelas interval. Rentang data dihitung dengan rumus nilai maksimal - nilai minimal, sehingga diperoleh rentang data sebesar $21-0=21$. Dengan diketahui rentang data dapat diperoleh panjang kelas sebesar 4,2.

Tabel distribusi frekuensi variabel pretest kemampuan belajar passing dengan menggunakan metode pembelajaran bermain disajikan Tabel 5. Berdasarkan distribusi frekuensi variabel pretest kemampuan belajar passing dengan menggunakan metode pembelajaran bermain tersebut terdapat pada Gambar 5. Berdasarkan Tabel 5 dan Gambar 5, frekuensi variabel pretest kemampuan belajar passing dengan menggunakan metode pembelajaran bermain mayo- ritas terdapat pada interval $0,0-4,2$ sebanyak 6 siswa $(50,0 \%)$, sedangkan paling sedikit terdapat pada interval 17,2-21,4 dan interval 8,612,8 masing-masing sebanyak 1 siswa $(8,3 \%)$. Sisanya berada pada interval 4,3-8,5 sebanyak 4 siswa $(33,3 \%)$, sedangkan interval 12,9-17,1 tidak ada.

\section{Posttest Kemampuan Belajar Passing} Menggunakan Metode Pembelajaran Bermain

Hasil posttest menunjukkan bahwa skor tertinggi yang dicapai siswa adalah 30,00 dan skor terendah sebesar 1,00. Dengan komputer program SPSS diketahui bahwa skor rerata (mean) yang diraih siswa pada saat posttest sebesar 8,92; median sebesar 7,00; mode sebesar 6,00, dan standar deviasi sebesar 7,51.

Selanjutnya jumlah kelas dapat dihitung dengan menggunakan rumus $1+3.3 \log \mathrm{n}$, dengan $\mathrm{n}$ adalah subjek penelitian. Dari perhitungan diketahui bahwa $n=12$ sehingga diperoleh banyak kelas $1+3.3 \log 12=4,6$ dibulatkan menjadi 5 kelas interval. Rentang data dihitung dengan rumus nilai maksimal-nilai minimal, sehingga diperoleh rentang data sebesar $30-1$ $=29$. Dengan diketahui rentang data dapat diperoleh panjang kelas sebesar 5,8.

Tabel distribusi frekuensi variabel postest kemampuan belajar passing dengan menggunakan metode pembelajaran bermain disajikan Tabel 6 .

Tabel 5. Distribusi Frekuensi Variabel Pretest Kemampuan Belajar Passing dengan Menggunakan Metode Pembelajaran Bermain

\begin{tabular}{ccccccc}
\hline No. & & Interval & & & Persentase & Klasifikasi \\
\hline 1. & 17,2 & & 21,4 & 1 & $8,3 \%$ & Baik sekali \\
2. & 12,9 & - & 1117,1 & 0 & $0,0 \%$ & Baik \\
3. & 8,6 & - & 112,8 & 1 & $8,3 \%$ & Sedang \\
4. & 4,3 & - & 8,5 & 4 & $33,3 \%$ & Kurang \\
5. & 0,0 & - & 4,2 & 6 & $50,0 \%$ & Kurang sekali \\
& \multicolumn{2}{c}{ Jumlah } & & 12 & $100,0 \%$ & \\
\hline
\end{tabular}

(Sumber: Data primer yang diolah, 2014)

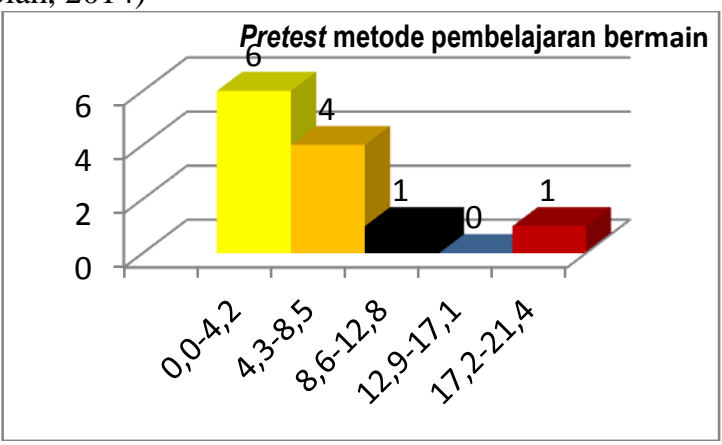

Gambar 5. Distribusi Frekuensi Variabel Pretest Kemampuan Belajar Passing dengan Menggunakan Metode Pembelajaran Bermain 
Jurnal Keolahragaan 4 (2), September 2016 - 215

S. Samsudin, Hari Amirullah Rahman

Tabel 6. Distribusi Frekuensi Variabel Posttest Kemampuan Belajar Passing dengan Menggunakan Metode Pembelajaran Bermain

\begin{tabular}{ccccccc}
\hline No. & & Interval & & Frekuensi & Persentase & Klasifikasi \\
\hline 1. & 24,6 & - & 30,4 & 1 & $8,3 \%$ & Baik sekali \\
2. & 18,7 & - & 24,5 & 0 & $0,0 \%$ & Baik \\
3. & 12,8 & - & 18,6 & 1 & $8,3 \%$ & Sedang \\
4. & 6,9 & - & 12,7 & 5 & $41,7 \%$ & Kurang \\
5. & 1,0 & - & 6,8 & 5 & $41,7 \%$ & Kurang sekali \\
\multicolumn{2}{c}{ Jumlah } & & 12 & $100,0 \%$ & \\
\hline
\end{tabular}

(Sumber: Data primer yang diolah, 2014)

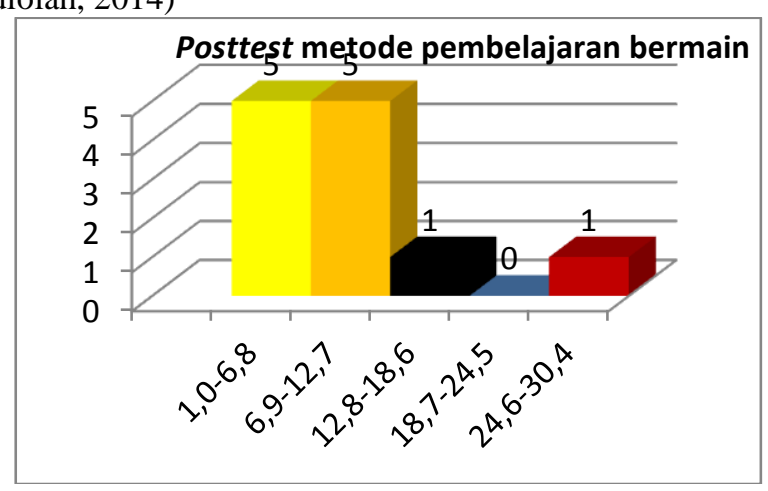

Gambar 6. Distribusi Frekuensi Variabel Posttest Kemampuan Belajar Passing Menggunakan Metode Pembelajaran Bermain

Berdasarkan distribusi frekuensi variabel posttest kemampuan belajar passing dengan menggunakan metode pembelajaran bermain di atas dapat digambarkan grafik sebagai berikut:

Berdasarkan Tabel 6 dan Gambar 6, frekuensi variabel posttest kemampuan belajar passing dengan menggunakan metode pembelajaran bermain mayoritas terdapat pada interval 1,0-6,8 dan interval 6,9-12,7 masing-masing sebanyak 5 siswa $(41,7 \%)$, sedangkan paling sedikit terdapat pada interval 12,8-18,6 dan interval 24,6-30,4 masing-masing sebanyak 1 siswa $(8,3 \%)$.

\section{Data Kelincahan}

Data kelincahan dalam penelitian ini menghasilkan dua macam data, yaitu data skor kelincahan yang menggunakan metode pembelajaran drill dan data skor kelincahan yang menggunakan metode pembelajaran bermain.
Data Kelincahan Metode Pembelajaran Drill

Hasil kelincahan menggunakan metode pembelajaran drill memiliki nilai terendah adalah 18,20 dan nilai tertinggi sebesar 27,04. Dengan komputer program SPSS diketahui bahwa skor rerata (mean) yang dicapai siswa sebesar 21,57; median sebesar 20,5; mode sebesar 19,49 dan standar deviasi sebesar 2,99.

Selanjutnya jumlah kelas dapat dihitung dengan menggunakan rumus $1+3.3 \log \mathrm{n}$, dengan $\mathrm{n}$ adalah subjek penelitian. Dari perhitungan diketahui bahwa $\mathrm{n}=12$ sehingga diperoleh banyak kelas $1+3.3 \log 12=4,6$ dibulatkan menjadi 5 kelas interval. Rentang data dihitung dengan rumus nilai maksimal - nilai minimal, sehingga diperoleh rentang data sebesar 27,0 $18,2=8,84$. Dengan diketahui rentang data dapat diperoleh panjang kelas sebesar 1,8 .

Tabel distribusi frekuensi variabel kelincahan dengan menggunakan metode pembelajaran drill disajikan Tabel 7.

Tabel 7. Distribusi Frekuensi Variabel Kelincahan Metode Pembelajaran Drill

\begin{tabular}{ccccccc}
\hline No. & & Interval & & Frekuensi & Persentase & Klasifikasi \\
\hline 1. & 25,8 & - & 27,6 & 2 & $16,7 \%$ & Baik sekali \\
\hline 2. & 23,9 & - & 25,7 & 0 & $0,0 \%$ & Baik \\
\hline 3. & 22,0 & - & 23,8 & 3 & $25,0 \%$ & Sedang \\
\hline 4. & 20,1 & - & 21,9 & 1 & $8,3 \%$ & Kurang \\
\hline 5. & 18,2 & - & 20,0 & 6 & $50,0 \%$ & Kurang sekali \\
\hline \multicolumn{7}{c}{ Jumlah } \\
\hline
\end{tabular}

(Sumber: Data primer yang diolah, 2014) 


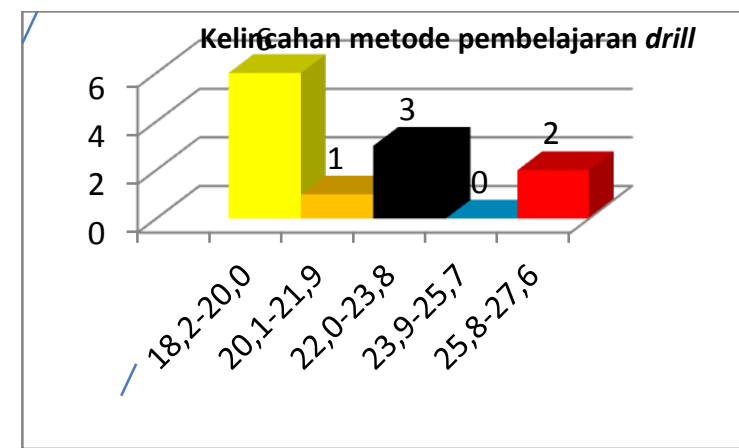

Gambar 7. Distribusi Frekuensi Variabel Kelincahan Metode Pembelajaran Drill

Tabel 8. Distribusi Frekuensi Variabel Kelincahan Metode Pembelajaran Bermain

\begin{tabular}{ccccccc}
\hline No. & & Interval & & frekuensi & Persentase & Klasifikasi \\
\hline 1. & 29,4 & - & 32,0 & 1 & $8,3 \%$ & Baik sekali \\
\hline 2. & 26,7 & - & 29,3 & 0 & $0,0 \%$ & Baik \\
\hline 3. & 24,0 & - & 26,6 & 2 & $16,7 \%$ & Sedang \\
\hline 4. & 21,3 & - & 23,9 & 4 & $33,3 \%$ & Kurang \\
\hline 5. & 18,6 & - & 21,2 & 5 & $41,7 \%$ & Kurang sekali \\
\hline \multicolumn{7}{c}{ Jumlah } \\
\hline
\end{tabular}

(Sumber: Data primer yang diolah, 2014)

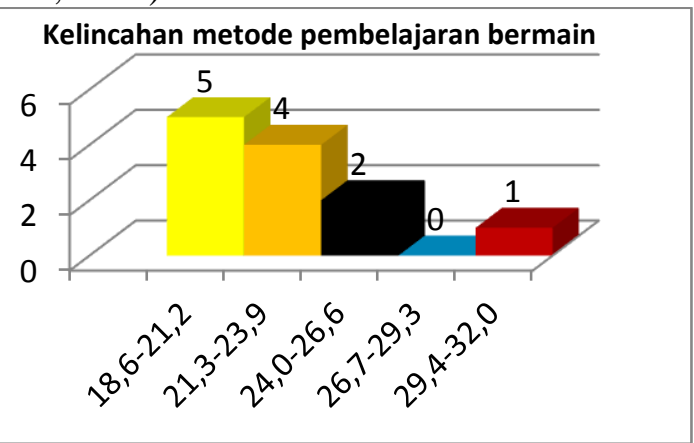

Gambar 8. Distribusi Frekuensi Variabel Kelincahan Metode Pembelajaran Bermain

Distribusi frekuensi variabel kelincahan dengan menggunakan metode pembelajaran drill tersebut disajikan Gambar 7. Berdasarkan Tabel 7 dan Gambar 7, frekuensi variabel kelincahan dengan menggunakan metode pembelajaran drill mayoritas terdapat pada interval 18,2-20,0 sebanyak 6 siswa $(50,0 \%)$, sedangkan paling sedikit terdapat pada interval 20,121,9 sebanyak 1 siswa $(8,3 \%)$.

Data Kelincahan Metode Pembelajaran Bermain

Data kelincahan dengan menggunakan metode pembelajaran bermain memiliki skor terendah adalah 18,60 dan skor tertinggi yang dicapai siswa adalah 31,40. Dengan komputer program SPSS diketahui bahwa skor rerata (mean) yang diraih siswa sebesar 22,41; median 21,56; mode sebesar 18,60; dan standar deviasi sebesar 3,71.

Selanjutnya jumlah kelas dapat dihitung dengan menggunakan rumus $1+3.3 \log n$, dengan $\mathrm{n}$ adalah subjek penelitian. Dari perhitungan diketahui bahwa $\mathrm{n}=12$ sehingga diperoleh banyak kelas $1+3.3 \log 12=4,6$ dibulatkan menjadi 5 kelas interval. Rentang data dihitung dengan rumus nilai maksimal nilai minimal, sehingga diperoleh rentang data sebesar $31,4-18,6=12,80$. Dengan diketahui rentang data dapat diperoleh panjang kelas sebesar 2,6.

Distribusi frekuensi variabel kelincahan dengan menggunakan metode pembelajaran bermain disajikan Tabel 8. Berdasarkan distribusi frekuensi variabel kelincahan dengan menggunakan metode pembelajaran bermain di atas dapat digambarkan grafik sebagai berikut:

Berdasarkan Tabel 8 dan Gambar 8, frekuensi variabel kelincahan dengan menggunakan metode pembelajaran bermain mayoritas terdapat pada interval 18,6-21,2 sebanyak 5 siswa $(41,7 \%)$, sedangkan paling sedikit terdapat pada interval 729,4-32,0 sebanyak 1 siswa $(8,3 \%)$. 


\section{Jurnal Keolahragaan 4 (2), September 2016 - 217}

S. Samsudin, Hari Amirullah Rahman

Perbedaan Pengaruh antara Metode Pembelajaran Drill dan Metode Pembelajaran Bermain terhadap Kemampuan Belajar Passing Bola Voli

Hasil penelitian menunjukkan bahwa ada perbedaan pengaruh antara kelompok siswa yang mendapatkan perlakuan metode pembelajaran drill dan kelompok siswa yang mendapatkan perlakuan metode pembelajaran bermain terhadap kemampuan belajar passing bola voli. Hal ini dibuktikan dari nilai signifikansi sebesar 0,003 lebih kecil dari nilai taraf signifikansi 5 $\%(0,003<0,05)$.

Berdasarkan nilai mean (rata-rata) kemampuan passing siswa melalui kedua metode pembelajaran mengalami perbedaan. Nilai mean pada metode pembelajaran drill lebih tinggi daripada metode pembelajaran bermain $(18,25$ > 8,92). Pada kelompok yang mendapatkan metode pembelajaran drill mempunyai peningkatan kemampuan passing bola voli yang lebih baik dibandingkan dengan kelompok yang mendapatkan perlakuan metode pembelajaran bermain. Hal ini dikarenakan metode pembelajaran drill cenderung mem-passing bola secara terus-menerus pada setiap sesi pembelajaran/ latihan sampai batas waktu yang ditetapkan. Hal ini membuat siswa dapat meningkatkan otomatisasi gerak dengan cepat. Sementara dalam metode pembelajaran bermain, penekanannya pada pengaplikasian lapangan, terutama pada penekanan secara fisik dan mental.

Metode pembelajaran drill dan metode pembelajaran bermain merupakan metode pembelajaran yang dapat digunakan dalam meningkatkan kemampuan passing pada permainan bola voli. Hal ini dikarenakan kedua metode pembelajaran tersebut memiliki banyak keunggulan. Keunggulan metode pembelajaran drill di antaranya tepat bagi siswa yang memiliki kemampuan persepsi gerak yang kurang baik, tepat untuk penguatan memori terhadap setiap gerak teknik yang diajarkan sehingga untuk pembentukan gerak teknik dapat dilakukan dengan cepat, bermanfaat untuk mendaptasi beban latihan yang relatif berat. Sementara keunggulan metode pembelajaran bermain dapat berkesan dengan kuat dan tahan lama dalam ingatan siswa, dikarenakan pada umumnya permainan terasa menyenangkan, tepat bagi siswa yang memilki kemampuan persepsi dan koordinasi gerak yang baik, membangkitkan gairah dan semangat optimisme dalam diri siswa serta menumbuhkan rasa kebersamaan dan sosial yang tinggi.

Dengan demikian, metode pembelajaran drill dan metode pembelajaran bermain dapat digunakan untuk mengembangkan kemampuan passing pada permainan bola voli.

Perbedaan Peningkatan Kemampuan Passing Bola Voli antara Metode Pembelajaran Drill Siswa yang Memiliki Kelincahan Tinggi dan Metode Pembelajaran Bermain Siswa yang Memiliki Kelincahan Tinggi

Hasil penelitian menunjukkan bahwa ada perbedaan peningkatan kemampuan passing bola voli antara metode pembelajaran drill siswa yang memiliki kelincahan tinggi dan metode pembelajaran bermain siswa yang memiliki kelincahan tinggi. Hal ini dibuktikan dari nilai signifikansi sebesar 0,000 lebih kecil dari nilai taraf signifikansi $5 \%(0,000<0,05)$. Dengan kelincahan yang sama tinggi dilatihkan dengan metode pembelajaran yang berbeda yaitu, metode pembelajaran drill dan metode pembelajaran bermain ternyata memberikan pengaruh yang berbeda terhadap peningkatan kemampuan passing bola voli.

Perbedaan peningkatan kemampuan passing siswa yang memiliki kelincahan tinggi antara metode pembelajaran drill dan metode pembelajaran bermain juga dapat dilihat pada nilai mean. Pada kemampuan passing siswa yang memiliki kelincahan tinggi dengan metode pembelajaran drill sebesar 27,33. Sementara kemampuan passing siswa yang memiliki kelincahan tinggi dengan metode pembelajaran bermain nilai mean-nya sebesar 12,33. Hal ini berarti kemampuan passing siswa yang memiliki kelincahan tinggi dengan metode pembelajaran drill lebih baik dibandingkan kemampuan passing siswa yang memiliki kelincahan tinggi dengan metode pembelajaran bermain.

Kelincahan sangat penting fungsingnya untuk meningkatkan prestasi dalam cabang olahraga. Kelincahan merupakan kemampuan seorang untuk dapat mengubah arah dengan cepat dan tepat pada waktu gerak atau berlari dengan kecepatan penuh tanpa kehilangan keseimbangan. Lebih lanjut, seseorang yang dapat mengubah pada posisi berbeda dalam kecepatan yang tinggi dengan koordinasi yang baik, berarti kelincahannya cukup baik. Secara langsung kelincahan dapat digunakan untuk mengkoordinasikan gerakan-gerakan berganda (simultan), mempermudah penguasaan teknik- 


\section{Jurnal Keolahragaan 4 (2), September 2016 - 218}

S. Samsudin, Hari Amirullah Rahman

teknik tinggi, mempermudah orientasi terhadap lawan dan lingkungan.

Dengan demikian, perbedaan peningkatan kemampuan passing siswa yang memiliki kelincahan tinggi antara metode pembelajaran drill dan metode pembelajaran bermain dapat menjadikan pertimbangan bagi guru olahraga dalam pembelajaran bola voli, khususnya kemampuan passing.

Perbedaan Peningkatan Kemampuan Passing Bola Voli antara Metode Pembelajaran Drill Siswa yang Memiliki Kelincahan Rendah dan Metode Pembelajaran Bermain Siswa yang Memiliki Kelincahan Rendah

Hasil penelitian menunjukkan bahwa ada perbedaan peningkatan kemampuan passing bola voli antara metode pembelajaran drill siswa yang memiliki kelincahan rendah dan metode pembelajaran bermain siswa yang memiliki kelincahan rendah. Hal ini dibuktikan dari nilai nilai signifikansi sebesar 0,000 lebih kecil dari nilai taraf signifikansi 5\% (0,000 < $0,05)$. Dengan kelincahan yang sama rendah dilatihkan dengan metode pembelajaran yang berbeda yaitu metode pembelajaran drill dan metode pembelajaran bermain memberikan pengaruh yang berbeda terhadap peningkatan kemampuan passing bola voli.

Perbedaan peningkatan kemampuan passing siswa yang memiliki kelincahan rendah antara metode pembelajaran drill dan metode pembelajaran bermain juga dapat dilihat pada nilai mean (rata-rata). Pada kemampuan passing siswa yang memiliki kelincahan rendah dengan metode pembelajaran drill sebesar 9,17. Sementara kemampuan passing siswa yang memiliki kelincahan rendah dengan metode pembelajaran bermain nilai mean-nya sebesar 5,50. Hal ini berarti kemampuan passing siswa yang memiliki kelincahan rendah dengan metode pembelajaran drill lebih baik dibandingkan kemampuan passing siswa yang memiliki kelincahan rendah dengan metode pembelajaran bermain.

Kelincahan merupakan perpaduan dari unsur kecepatan, fleksibilitas, dan koordinasi. Kelincahan bukan murni unsur kebugaran otot tetapi hasil perpaduan dari beberapa unsur. $\mathrm{Ke}$ lincahan berkaitan dengan tingkat kelentukan, tanpa kelentukan orang tidak dapat begerak dengan lincah dan keseimbangan sangat berpengaruh terhadap kemampuan kelincahan (Sukadiyanto, 2011, p.93). Oleh karena itu, untuk dapat meningkatkan kelincahan dapat digunakan metode pembelajaran drill dan metode pembelajaran bermain.

Interaksi antara Metode Pembelajaran dan Kelincahan terhadap Kemampuan Passing Bola Voli

Hasil penelitian menunjukkan bahwa ada interaksi antara metode pembelajaran dan kelincahan terhadap kemampuan passing bola voli. Hal ini dibuktikan dari nilai signifikansi sebesar 0,049 lebih kecil dari nilai taraf signifikansi 5 $\%(0,049<0,05)$. Hal ini berarti peningkatan kemampuan passing tidak dipengaruhi oleh kedua metode pembelajaran saja tetapi juga faktor kelincahan, yang kedua faktor tersebut memengaruhi secara berkaitan. Tinggi rendahnya kelincahan yang dimiliki siswa dapat memengaruhi kemampuan passing. Dengan kata lain, siswa yang memiliki kelincahan tinggi akan lebih optimal dalam melakukan passing dibandingkan siswa yang memiliki kelincahan rendah.

Penggunaan metode pembelajaran dalam kemampuan passing dapat dijadikan sebagai salah satu sarana untuk meningkatkan koordinasi mata dan tangan. Untuk terbentuknya kekuatan yang memadai, seseorang harus memiliki kelincahan. Metode pembelajaran drill membutuhkan kelincahan yang lebih tinggi dikarenakan program pembelajaran/latihan yang efektif dengan adanya waktu istirahat selama 30 detik untuk meningkatkan kekuatan, koordinasi, ketahanan, dan pembentukan otot. Di sisi lain, metode pembelajaran bermain tidak terlalu membutuhkan kelincahan yang tinggi karena program pembelajaran/latihan yang sangat baik untuk meningkatkan eksplosif dan koordinasi.

Dengan demikian dapat disimpulkan bahwa peningkatan kemampuan passing tidak hanya dipengaruhi oleh kedua metode pembelajaran saja tetapi juga faktor kelincahan, yang kedua faktor tersebut memengaruhi secara berkaitan.

\section{SIMPULAN}

Berdasarkan hasil penelitian dan pembahasan dapat ditarik beberapa kesimpulan sebagai berikut: (1) ada perbedaan pengaruh antara metode pembelajaran drill dan metode pembelajaran bermain terhadap kemampuan belajar passing bola voli, (2) ada perbedaan peningkatan kemampuan passing bola voli antara metode pembelajaran drill siswa yang memiliki kelincahan tinggi dengan metode pembelajaran bermain siswa yang memiliki kelin- 
cahan tinggi, (3) ada perbedaan peningkatan kemampuan passing bola voli antara metode pembelajaran drill siswa yang memiliki kelincahan rendah dan metode pembelajaran bermain siswa yang memiliki kelincahan rendah, dan (4) ada interaksi antara metode pembelajaran dan kelincahan terhadap kemampuan passing bola voli.

\section{DAFTAR PUSTAKA}

Arikunto, S. (2010). Prosedur penelitian suatu pendekatan praktis. Jakarta: Rineka Cipta.

Getchell. (1979). Illinois agility test. Diakses pada tanggal 7 Maret 2013, dari http://www.infofisioterapi.com/illinoisagility-run-test.

Miller, D. K. (2002). Measurement by the physical educator: why and now. New York: Avenue of the Americas.
Ngatman. (2001). Petunjuk praktikum tes dan pengukuran. Yogyakarta: Program Studi Pendidikan Kesehatan dan Rekreasi FIK UNY.

Sudjana. (2002). Desain analisis eksperimen. Bandung: Transito.

Sudjana, N. (2013). Dasar-dasar proses belajar mengajar. Bandung: Sinar Baru Algensindo.

Sukadiyanto. (2010). Pengantar teori metodologi melatih fisik: Yogyakarta: FIK UNY.

Wahyuni, S., \& Sutarmin. (2012). Pendidikan jasmani, olahraga, dan kesehatan, untuk kelas X SMA dan MA. Solo: PT Tiga Serangkai Pustaka Mandiri. 